\title{
Effects of Growth Hormone on Insulin Release in the Rat
}

\author{
J. Pierluissi, R. Pierluissi, and S. J.H. Ashcroft \\ Nuffield Department of Clinical Biochemistry, John Radcliffe Hospital, Headington, Oxford, England
}

Summary. Growth hormone injected intravenously in the rat elicited a 6-fold spike change in immunoreactive insulin with little variation in glucose. Subcutaneous administration of growth hormone for 4 days augmented by $56 \%$ the insulin-secretory response to glucose of isolated islets from hypophysectomised rats but not the response of control rat islets. When islets were cultured in the presence of growth hormone, the glucose-induced insulin release was increased by $35 \%$ in batch incubations of islets from both normal and hypophysectomised rats and by $70-110 \%$ in perifused islets. Thus the capacity for stimulated release of insulin is limited by hypophysectomy, and growth hormone is capable of directly influencing the secretory function of the $\beta$ cell.

Key words: Growth hormone, hypophysectomy, plasma growth hormone, plasma insulin, insulin release, perifusion, cultured rat islets.

Growth hormone is known to regulate carbohydrate metabolism in dogs and other species $[1,2]$. In the dog, administration of growth hormone $(\mathrm{GH})$ causes diabetes [3, 4] accompanied by hyperinsulinaemia [5], followed after prolonged $\mathrm{GH}$ treatment by lowered insulin secretion [6]. In the rat, GH, while not diabetogenic, is able to induce signs of enhanced pancreatic activity $[7,8]$. In hypophysectomised but not in normal rats, repeated injections of growth hormone restores to a variable extent the insulin-release response of pancreatic islets incubated with glucose $[9,10]$. In the present experiments, we have sought further information on plasma insulin after intrave- nous injection of growth hormone in normal rats, and on the insulin response to glucose of islets treated directly with growth hormone in culture.

\section{Materials and Methods}

\section{Reagents}

All chemicals used were of analytical grade. Bovine growth hormone (bGH, National Institutes of Health, U. S. A., lots NIH-GH $\mathrm{S} 11$ and NIH-GHB 18) was dissolved fresh before use $(5 \mathrm{mg} / \mathrm{ml}$ in $0.154 \mathrm{~mol} / 1 \mathrm{NaCl}$ at $\mathrm{pH} 8$ ). The $\mathrm{bGH}$ solution was insulin-free by radioimmunoassay (RIA) and also free of glucose. Rat insulin standard was a gift from Dr. A. J. Moody, Novo Research Laboratories. Guinea pig anti-insulin serum (Wellcome, lot K6440), and a suspension of charcoal (Norit GSX) were used for insulin, radioimmunoassay. Collagenase (Type I) and bovine plasma albumin were from Sigma. ATP, NADP, glucose-6phosphate dehydrogenase (E.C. 1.1.1.49) and hexokinase (E. C. 2. 7. 1. 1.) were from Boehringer. For islet culture, tissue culture medium (Gibco, RPMI-1640 with $25 \mathrm{mmol} / \mathrm{l}$ HEPES) containing $11 \mathrm{mmol} / 1$ glucose, $0.5 \mathrm{mg} / \mathrm{ml}$ streptomycin, 150 units/ $\mathrm{ml}$ penicillin and $10 \%$ inactivated normal calf serum (Wellcome, C507) was used in sterile petri dishes.

\section{Animals}

Male hypophysectomised rats and paired controls of the Wistar strain were purchased from Charles River Laboratories, and used after 4-5 weeks from hypophysectomy. Regular rat diet (PRM, E. Dixon \& Sons (Ware) Ltd.) was supplemented with $5 \mathrm{~g} / 100 \mathrm{ml}$ sucrose in water and free access to $\mathrm{NaCl}$ tablets. Other rats were from the laboratory stock, belonged to the same strain and sex, and were fed on a regular rat diet only.

\section{Injection of Growth Hormone}

Normal fed rats of $485-520 \mathrm{~g}$ body weight were used. Both left femoral vein and artery were cannulated (nylon cannulae, Portex) under sodium pentobarbitone anaesthesia $(20 \mathrm{mg} / \mathrm{kg}$ body weight SC, Sagatal). After cannulation, rats were kept in restraining cages and tests performed $2 \mathrm{~h}$ after recovery. In 3 rats, bGH, $2 \mathrm{mg} / \mathrm{kg}$ 
body weight, was injected subcutaneously. Arterial blood samples $(0.5 \mathrm{ml})$ were taken at $0,15,30,60,180$ and $360 \mathrm{~min}$. After this test, and in the same rats, bGH $(2 \mathrm{mg} / \mathrm{kg}$ body weight in $0.2 \mathrm{ml}$ $0.154 \mathrm{~mol} / 1 \mathrm{NaCl}, \mathrm{pH} 8$ ) was injected via femoral vein, and arterial blood samples $(0.5 \mathrm{ml})$ collected at intervals from $0-60 \mathrm{~min}$. In another 7 rats, cannulated in an identical way, an intravenous bGH test was preceded by a saline injection test $(0.2 \mathrm{ml} 0.154 \mathrm{~mol} / 1$ $\mathrm{NaCl} \mathbf{p H} 8$ ). In each test, arterial blood samples were collected from -5 to $30 \mathrm{~min}$. Plasma samples obtained by centrifugation, were stored at $-20^{\circ} \mathrm{C}$ until analysed. $b G H, 10 \mathrm{mg} / \mathrm{kg}$ body weight, was also injected subcutaneously for 4 days in 5 normal and 5 hypophysectomised rats, and the insulin response to glucose of isolated islets was compared with that of islets from paired control rats injected identically with the same volume of solvent $(0.154 \mathrm{~mol} / \mathrm{l} \mathrm{NaCl} \mathrm{pH} 8)$.

\section{Preparation of Islets}

Islets from hypophysectomised rats $(140-200 \mathrm{~g}$ body weight $)$ and their pair-fed controls (390-500 g body weight) and from stock control rats $(200-350 \mathrm{~g}$ body weight) were prepared by the collagenase method [11]. To minimize variation in response due to varying food intake, rats were fasted overnight when islets were to be used immediately without prior culture. Islets to be cultured were obtained from fed rats.

\section{Culture of Islets}

Islets were cultured at $37^{\circ} \mathrm{C}$ in an atmosphere of humidified air: $\mathrm{CO}_{2}(95: 5)$ in the medium previously described [12]. Usually, 25 islets in $5 \mathrm{ml}$ of medium were cultured with change of medium every $48 \mathrm{~h}$. Islets from normal and hypophysectomised rats were cultured in the presence or absence of growth hormone $(10 \mu \mathrm{g} / \mathrm{ml})$ for 4 days, after which insulin release in the absence of bGH was studied. In one series of experiments, after measurement of glucose-stimulated insulin release, the islets were transferred to culture medium without growth hormone for 4 days followed by a second study of insulin release.

\section{Perifusion of Islets}

A specially designed chamber-bath was used. This consisted of a plexiglass central perifusion chamber $(0.1 \mathrm{ml})$ with an outer bath $(70 \mathrm{ml})$ maintaining temperature at $37^{\circ} \mathrm{C}$ by a circulating pump coupled to a thermocontrolled bath. The solution was perifused upward by a peristaltic pump at the flow rate of $2.5 \mathrm{ml} / \mathrm{min}$. The perifusion solutions were kept at $37^{\circ}$ prior to circulation through the chamber and were constantly gassed $\left(\mathrm{O}_{2}: \mathrm{CO}_{2}, 95: 5, \mathrm{v}: \mathrm{v}\right)$. Solutions consisted of Krebs-Ringer bicarbonate, $\mathrm{pH} 7.4$ [13] containing bovine plasma albumin $(0.5 \mathrm{~g} / 100 \mathrm{ml})$ and glucose as indicated. Islets prepared from two hypophysectomised and two paired control rats were cultured for 4 days in the absence or presence of $10 \mu \mathrm{g} / \mathrm{ml} \mathrm{bGH}$. Fifty islets from each type were transferred to each chamber filled with medium. After an equilibration of $45 \mathrm{~min}$ with $2 \mathrm{mmol} / 1$ glucose, 5 -min fractions were collected for $25 \mathrm{~min}$. Then, perifusion with $20 \mathrm{mmol} / 1$ glucose was started and 1 -min fractions were obtained for $10 \mathrm{~min}$ followed by 5 -min samples for an additional 100-min period. Insulin was measured immediately for each experiment, after appropriate dilution of an aliquot of the sample with the RIA buffer. Insulin release was expressed as $\mu \mathrm{U} / \mathrm{min}$ per islet and also as the area under the release curve ( $\mu \mathrm{U}$ per islet).

\section{Incubation of Batches of Islets for Insulin Release}

Islets were incubated in batches of 5 in $0.6 \mathrm{ml} \mathrm{Krebs-bicarbonate}$ medium [13] $\mathrm{pH} 7.4$, containing bovine plasma albumin, $1 \mathrm{~g} / 1$, and glucose in the indicated concentrations, and gassed with $\mathrm{O}_{2}: \mathrm{CO}_{2}$, $95: 5, \mathrm{v}: \mathrm{v}$, prior to incubation. Afterwards, the islets were settled by centrifugation (position 1, MSE Minor bench centrifuge) and an aliquot of the supernatant was removed. This was suitably diluted with the RIA buffer, and kept at $-20^{\circ} \mathrm{C}$ until insulin assay.

\section{Islet Content of Insulin}

Batches of 4 islets were extracted in $0.25 \mathrm{ml} 0.154 \mathrm{~mol} / 1 \mathrm{NaCl}, \mathrm{pH}$ 2 , by sonication ( $15 \mathrm{sec}$ at position 2 on a Soniprobe, Dawe Instruments). The sonicate was diluted and assayed for insulin.

\section{Islet Diameter}

Islet diameter was measured using an eye-piece micrometer in a Griffin stereoscopic dissecting microscope.

\section{Assay}

Immunoreactive bGH was measured by a specific radioimmunoassay [14]. Immunoreactive insulin both in plasma and media was estimated by a charcoal radioimmunoassay [15]. The minimum detectable insulin concentration was $5 \mathrm{mU} / 1$ and the coefficient of variation $5 \%$. Growth hormone at concentrations up to $20 \mu \mathrm{g} / \mathrm{ml}$ did not interfere with the radioimmunoassay of insulin. Plasma glucose was determined by the hexokinase method [16]. Values are presented as means \pm SEM (shown in Figures as vertical lines). The probability $(\mathrm{P})$ of no real difference between means was calculated by two-tailed Student's t-test [17]; differences were considered to be significant for $P<0.05$. For calculation of $S E M$ and $\mathrm{t}$-test, $\mathrm{n}$-values were the number of rats for in vivo experiments and the number of batches of islets pooled from several rats for in vitro studies.

\section{Results}

\section{Insulin Secretion in Normal Rats In Vivo}

The effects of intravenous bovine growth hormone (bGH) injection on the plasma levels of immunoreactive insulin (IRI) and glucose are compared in Figure 1 with the effects of prior infusion of saline into the same rats. Values of IRI at 0 min were $23 \pm$ 5 and $25 \pm 4 \mathrm{mU} / 1$ before saline and bGH injections respectively: levels of glucose were respectively 4.5 \pm 0.3 and $5.6 \pm 0.5 \mathrm{mmol} / 1$. The control administration of saline produced no significant change in insulin concentrations. A slow rise in glucose concentrations was observed which did not attain statistical significance. Injection of bGH elicited a marked and prompt increase in IRI. The changes in glucose concentration were not significantly different from those seen at the same time-points during the previous saline injection. 
Table 1. Effects of the administration of growth hormone in vivo on the response to glucose of isolated pancreatic islets

\begin{tabular}{lllllll}
\hline Group & Rat condition & No. of rats & $\mathrm{GH}^{\mathrm{a}}$ & Body weight $\mathrm{g}$ & $\begin{array}{l}\text { IRI, } \mu \mathrm{U} / \mathrm{h} / \mathrm{per}_{\mathrm{islet}}^{\mathrm{b}} \\
\text { at glucose, } \mathrm{mmol} / \mathrm{l}\end{array}$ \\
\cline { 3 - 7 } & & & & 2 & 20 \\
\hline A & Hypophysectomised & 5 & + & $172 \pm 5$ & $37 \pm 3(25)$ & $272 \pm 20(25$ \\
B & Hypophysectomised & 5 & - & $158 \pm 9$ & $33 \pm 2(25)$ & $174 \pm 13(25)$ \\
C & Control & 5 & + & $393 \pm 19$ & $36 \pm 2(23)$ & $317 \pm 24(23)$ \\
D & Control & 5 & - & $392 \pm 17$ & $40 \pm 2(25)$ & $343 \pm 30(25)$ \\
\hline
\end{tabular}

${ }^{a}$ Bovine growth hormone, $10 \mathrm{mg} / \mathrm{kg}$ body weight per day, $\mathrm{SC}$, for 4 days

${ }^{b}$ Values for rates of IRI release are given as mean \pm SEM for the number of batches of islets shown in parentheses

Rates of insulin release at $2 \mathrm{mmol} / 1$ glucose were not significantly different in groups A-D. Rates of insulin release at $20 \mathrm{mmol} / 1 \mathrm{glucose}$ were significantly lower $(\mathrm{P}<0.001)$ in group B than in groups $\mathrm{A}, \mathrm{C}$ or $\mathrm{D}$. Rates of insulin release at $20 \mathrm{mmol} / 1$ glucose were significantly greater than at $2 \mathrm{mmol} / \mathrm{l}$ glucose for groups $\mathrm{A}-\mathrm{D}$

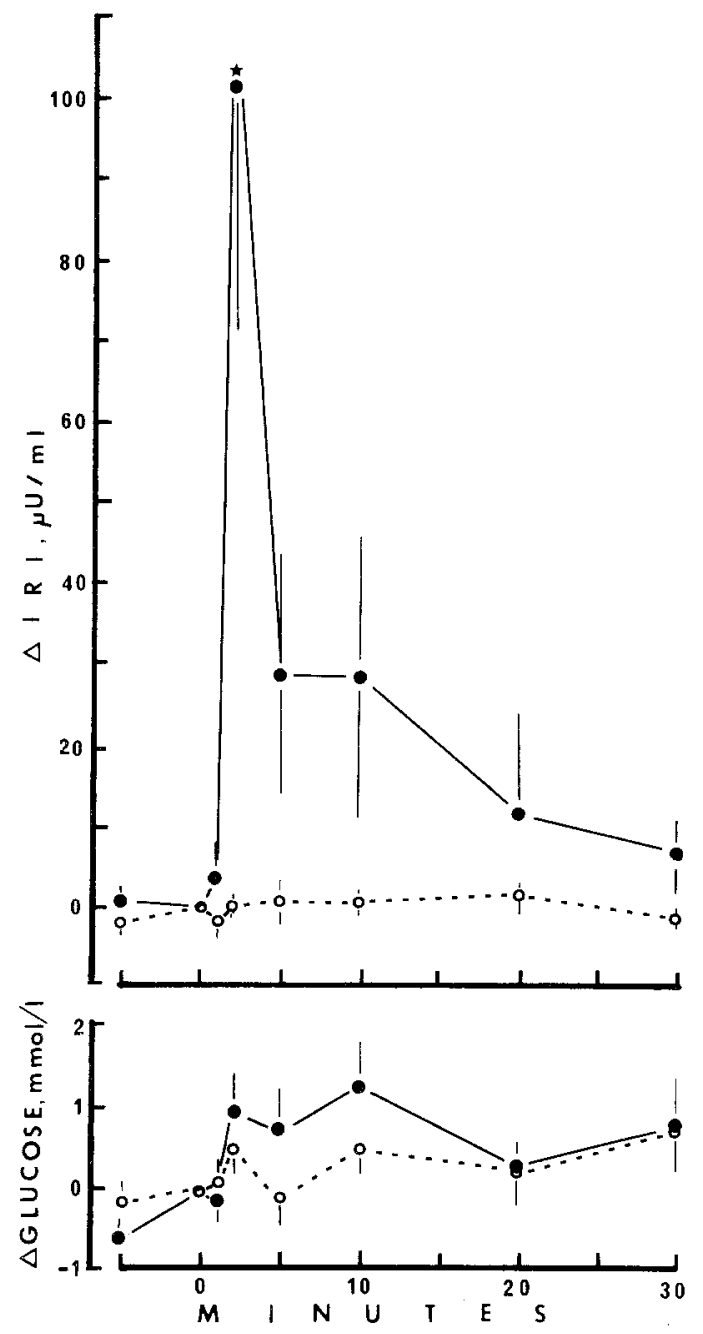

Fig. 1. Effects of intravenous injection of growth hormone on changes in plasma IRI and glucose. Values are given as the difference from value at time zero, expressed as mean \pm SEM for 7 rats. bGH test (—) followed immediately after control test $\left(O_{-}--O\right)$. An asterisk placed above the value at 2 min indicates a significant difference from value at zero min $(\mathrm{P}<0.02)$. The mean preinjection values for IRI and glucose were $24 \mu \mathrm{U} / \mathrm{ml}$ and $5.0 \mathrm{mmol} / 1$, respectively
Table 2. Effect of growth hormone added to pancreatic islets in culture on glucose-induced insulin release

\begin{tabular}{lllll}
\hline $\begin{array}{l}\text { Group } \\
\text { condition }\end{array}$ & $\begin{array}{l}\text { Rat of } \\
\text { rats }\end{array}$ & $\mathrm{GH}^{\mathrm{a}} \begin{array}{l}\text { IRI, } \mu \mathrm{U} / \mathrm{h} \text { per islet } \\
\text { at glucose, } \mathrm{mmol} / 1\end{array}$ \\
\cline { 3 - 5 } & & & 2 & 20 \\
\hline $\mathrm{A}$ & $\begin{array}{l}\text { Hypophy- } \\
\text { sectomised }\end{array}$ & 6 & + & $29 \pm 2(10) 280 \pm 13(22)$ \\
$\mathrm{B}$ & $\begin{array}{l}\text { Hypophy- } \\
\text { sectomised }\end{array}$ & 6 & - & $23 \pm 3(10) 204 \pm 12(20)$ \\
$\mathrm{C}$ & Control & 7 & + & $22 \pm 3(35) 410 \pm 19(35)$ \\
$\mathrm{D}$ & Control & 7 & - & $15 \pm 2(32) 306 \pm 21(32)$ \\
\hline
\end{tabular}

${ }^{a}$ Bovine growth hormone, $10 \mu \mathrm{g} / \mathrm{ml}$ of culture medium for 4 days, followed by batch incubations in the absence of bGH

${ }^{b}$ Rates of IRI release are given as mean \pm SEM for the no. of batches of islets shown in parentheses

Rates of IRI release at $2 \mathrm{mmol} / 1$ glucose were not significantly different in groups A-D. Rates of IRI release at $20 \mathrm{mmol} / 1$ glucose were significantly greater $(\mathrm{P}<0.001)$ than at $2 \mathrm{mmol} / 1$ glucose for groups A-D. For rates of IRI release at $20 \mathrm{mmol} / 1$ glucose, significant differences $(P<0.001)$ were found between groups $A$ vs $B$; $A$ vs $C ; B$ vs $C ; B$ vs $D ; C$ vs $D$; but groups $A$ and $D$ were not significantly different $(\mathrm{P}>0.05)$

The plasma levels of bGH attained were investigated in a further group of 3 rats given the same dose of bGH. IRbGH was increased by $17 \pm 3,14 \pm 2$ and $10 \pm 3 \mathrm{mg} / \mathrm{l}(\mathrm{P}<0.05-<0.001)$ at 2,5 and 10 min, respectively. For comparison, in the same rats injected subcutaneously with the same dose of bGH, the plasma levels of IRbGH rose to a maximum of $26-140 \mu \mathrm{g} / \mathrm{l}$ in $1 \mathrm{~h}$, returning to basal at $2 \mathrm{~h}$. IRI concentrations showed no significant change $(21 \pm 6$ and $26 \pm 14 \mathrm{mU} / 1$ at 0 and $1 \mathrm{~h}$, respectively).

\section{Basal IRI Levels}

Plasma IRI and glucose were also measured in 12 fed hypophysectomised rats and their fed paired con- 
Table 3. Insulin response to glucose of pancreatic islets after sequential periods of culture in the presence or absence of growth hormone

\begin{tabular}{|c|c|c|c|c|c|c|c|}
\hline \multirow[t]{3}{*}{ Group } & \multirow[t]{3}{*}{ Rat condition } & \multirow[t]{3}{*}{ No. of rats } & \multirow[t]{3}{*}{$\mathrm{GH}^{\mathrm{a}}$} & \multicolumn{4}{|c|}{ IRI, $\mu \mathrm{U} / \mathrm{h}$ per islet at glucose, $\mathrm{mmol} / \mathrm{l}$} \\
\hline & & & & \multicolumn{2}{|c|}{ After first culture } & \multicolumn{2}{|c|}{ After second culture } \\
\hline & & & & 2 & 20 & 2 & 20 \\
\hline A & Hypophysectomised & 5 & + & $17 \pm 8(3)$ & $339 \pm 25(8)$ & $15 \pm 4(3)$ & $289 \pm 24(8)$ \\
\hline B & Hypophysectomised & 5 & - & $22 \pm 3(3)$ & $247 \pm 28(8)$ & $27 \pm 4(3)$ & $83 \pm 18(8)$ \\
\hline $\mathrm{C}$ & Control & 5 & + & $21 \pm 3(6)$ & $563 \pm 33(9)$ & $25 \pm 5(6)$ & $272 \pm 20(9)$ \\
\hline $\mathrm{D}$ & Control & 5 & - & $21 \pm 1(6)$ & $419 \pm 23(9)$ & $23 \pm 3(6)$ & $114 \pm 11(9)$ \\
\hline
\end{tabular}

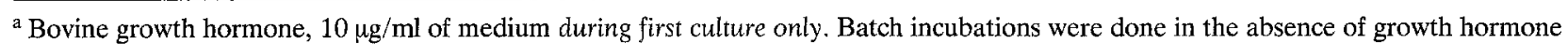

${ }^{\mathrm{b}}$ Rates of IRI release are given as mean \pm SEM for the number of batches of islets shown in parentheses. No significant differences were observed with islets incubated at $2 \mathrm{mmol} / \mathrm{l}$ glucose

Rates of IRI release at $20 \mathrm{mmol} / 1$ glucose were significantly greater $(\mathrm{P}<0.001)$ than at $2 \mathrm{mmol} / \mathrm{l}$ glucose for groups $\mathrm{A}-\mathrm{D}$, after the first and second culture periods. For rates of IRI release at $20 \mathrm{mmol} / 1$ glucose after the first culture period significant differences $(\mathrm{P}<0.05-<0.001)$ were found between groups A vs B; A vs C; A vs D; B vs C; B vs D; C vs D; after the second culture period, rates of IRI release at $20 \mathrm{mmol} / \mathrm{l}$ glucose were significantly different $(P<0.001)$ for groups $A$ vs $B ; A$ vs $D ; C$ vs $D ;$ but not for groups $A$ vs $C ; B$ vs $D(P>0.05)$

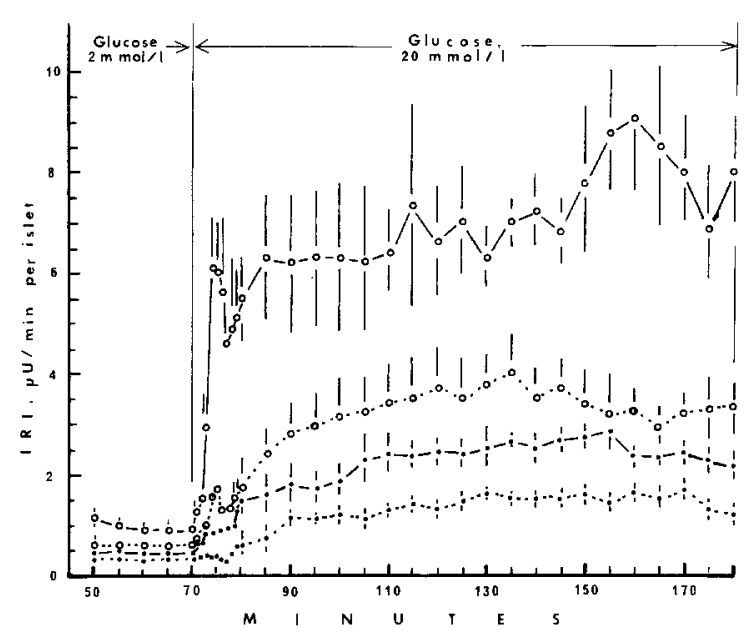

Fig. 2. Insulin responses to glucose of perifused islets from normal (open circles) and hypophysectomised (closed circles) rats after culture for 4 days in the absence (dotted lines) or presence of $10 \mu \mathrm{g} / \mathrm{ml}$ bGH (solid lines). Results are given as mean \pm SEM of 5 experiments. Rates of insulin release at $2 \mathrm{mmol} / \mathrm{l}$ glucose of bGHtreated islets from normal rats were higher than rates of other 3 groups of islets $(P<0.05)$. Rates of insulin release at $20 \mathrm{mmol} / \mathrm{l}$ glucose of bGH-treated islets from normal rats were higher than those of normal rat islets, not treated with bGH $(\mathrm{P}<0.05-<0.01$, $72-85 \mathrm{~min}$ and $130-180 \mathrm{~min}$ ) and also higher than rates of release of hypophysectomised rat islets, treated or not with bGH $(\mathrm{P}<0.05-<0.001,70-180 \mathrm{~min})$. Rates of insulin release at $20 \mathrm{mmol} / \mathrm{l}$ glucose of bGH-treated islets from hypophysectomised rats were higher than those of hypophysectomised rat islets not treated with bGH $(\mathrm{P}<0.05$ at $75 \mathrm{~min} ; \mathrm{P}<0.05-<0.001$, from 105-180 min)

trols. IRI was $27 \pm 6 \mathrm{mU} / 1$ for the controls and $5 \pm$ $1 \mathrm{mU} / 1$ for the hypophysectomised rats $(\mathrm{P}<0.001)$. Glucose levels were $6.2 \pm 0.2$ and $4.2 \pm 0.3 \mathrm{mmol} / 1$ respectively $(\mathrm{P}<0.001)$.

\section{Release of Insulin by Islets after In Vivo Treatment with Growth Hormone}

In hypophysectomised rats, bGH given $\mathrm{SC}$ for 4 days increased the insulin secretory response to $20 \mathrm{mmol} / \mathrm{l}$ glucose of the pancreatic islets by $56 \%(\mathrm{P}<0.001)$ above the response of the islets from hypophysectomised rats not treated with bGH (Table 1). The enhancement brought the secretory rate to $86 \%$ of bGH-treated paired controls. However, there was no difference in the response to glucose of islets from the normal rats compared with those from normal rats given bGH subcutaneously. Neither hypophysectomy nor bGH treatment affected the basal rate of insulin release from islets incubated with $2 \mathrm{mmol} / \mathrm{l}$ glucose.

\section{Release of Insulin by Cultured Islets}

bGH added during culture for 4 days enhanced the response to $20 \mathrm{mmol} / \mathrm{l}$ glucose of islets from hypophysectomised and normal rats by $37 \%$ and $34 \%$ respectively $(\mathrm{P}<0.001$, Tables $2-3)$. When the islets were cultured for a further 4 days in the absence of bGH (Table 3) the responses to $20 \mathrm{mmol} / \mathrm{l}$ glucose of islets from hypophysectomised rats were not significantly different from those from control rats. However, for both groups of islets, glucosestimulated insulin release rates were approximately 3-fold higher with islets exposed to bGH during the first culture period.

\section{Release of Insulin by Perifused Islets}

The release of insulin by perifused islets from normal and hypophysectomised rats cultured with or without bGH is shown in Figure 2. The basal secretion at 
$2 \mathrm{mmol} / 1$ glucose was slightly lower in islets from hypophysectomised rats whether or not bGH was present during culture. The response to $20 \mathrm{mmol} / 1$ glucose was higher in the control islets than in the islets from hypophysectomised rats, both in the initial and second phases. The presence of bGH during the culture period markedly enhanced the secretory response to $20 \mathrm{mmol} / 1$ glucose of perifused islets from both control and hypophysectomised rats. The integrated areas under the release curves from 70-180 min were as follows ( $\mu \mathrm{U} /$ islet): control -bGH: $325 \pm 59$; control +bGH: $674 \pm 50$; hypophysectomised - bGH: $133 \pm 8$; hypophysectomised +bGH: $224 \pm 25$. The culture with bGH enhanced the release response to glucose alone by $107 \%(\mathrm{P}<0.01)$ and $68 \%(\mathrm{p}<0.001)$ in the perifused control and hypophysectomised rat islets respectively.

\section{Islet Diameter and Insulin Content}

In islets from normal rats cultured for 4 days the mean islet diameter was $218 \pm 9 \mu \mathrm{m}(\mathrm{n}=31)$ and the mean insulin content was $2.7 \pm 0.2 \mathrm{mU} /$ islet $(\mathrm{n}=7)$. These parameters were not significantly different in islets obtained from hypophysectomised rats nor in islets from normal or hypophysectomised rats when bGH was present in the culture medium.

\section{Discussion}

The intravenous injection of bGH in the rat produced a marked increase in plasma IRI, in agreement with the effects observed in dogs after subcutaneous [18] or intravenous [19] administration of bGH. This increase in IRI was not mediated by changes in blood glucose concentration, and in view of its rapidity may represent a direct action of GH on insulin secretion since growth hormone intermediary hormones [20] may not be involved at this stage. Moreover, although glucagon has been shown to be reieased by $\mathrm{GH}$ even before insulin $[21,22]$ and could therefore mediate $\mathrm{GH}$-induced insulin release, the presence of high glucose levels abolishes GH-elicited glucagon release but amplifies the effect of $\mathrm{GH}$ on insulin release [21]. In the present study, the plasma concentration of bGH attained by IV injection was greatly above the physiological range. However, physiological concentrations of bGH have been shown to elicit insulin release in the perfused rat pancreas [21] and in the dog in vivo [19]. To avoid the complexities of the in vivo situation, we therefore studied the secretory behaviour of isolated islets of Langerhans.
The insulin secretory response to glucose of freshly-prepared islets was profoundly influenced by the $\mathrm{GH}$ status of the donor rats. In batch-type incubations, we found, as others $[9,10]$, that glucosestimulated insulin release was impaired in islets from hypophysectomised rats. Repeated injections of bGH restored to $86 \%$ of normal the capacity of the islets from hypophysectomised rats to secrete insulin in response to glucose but did not enhance secretion in islets from normal rats. The impaired secretory response to glucose of islets from hypophysectomised rats persisted throughout a culture period of 4 days and was evident in both batch-type and perifusion experiments. Since secretory data were expressed on a per islet basis, it was important to assess the effect of treatment of the rat on islet mass and $\beta$-cell content. It was shown that cultured islets from hypophysectomised rats were of identical size and insulin content to those from normal rats.

The cultured islet preparation permitted demonstration of a direct effect of $\mathrm{GH}$ on islet function in the absence of extrapancreatic factors. The addition of bGH to the culture medium markedly enhanced the insulin secretory response to glucose of islets from hypophysectomised rats and also of islets from control rats in both batch-type and perifusion experiments. Basal insulin release in batch-type experiments was not affected by hypophysectomy or bGH treatment of the rats nor by the addition of bGH to the culture medium. In perifusion experiments, a marginally lower rate of basal insulin release was observed in islets from hypophysectomised rats.

After 8 days in culture, the effect of hypophysectomy on the insulin response to glucose was no longer apparent; a diminished response to glucose was seen compared with 4-day cultured islets in both normal and hypophysectomised groups. However, despite the absence of bGH during the second 4-day culture period, there was a dramatic enhancement of insulin response to glucose in islets that had been cultured with bGH during the first culture period.

It is clear therefore that high concentrations of bGH can produce marked and persistent effects on insulin secretion in addition to an acute effect. The time required for the appearance of the lasting effect both in the GH-treated hypophysectomised rat and directly in the cultured islets is relatively long. Changes related to the biosynthesis of insulin and other proteins within the $\beta$-cell may be suggested. The possibility afforded by the present study of obtaining populations of islets with a modified insulin secretory function represents a useful approach to defining the mechanisms involved in the normal secretory response as well as its modifications by $\mathrm{GH}$. Assessment of the physiological relevance of the lat- 
ter now requires studies with physiological concentrations of GH. Such studies may require the use of rat $\mathrm{GH}$, although high affinity receptors for bGH have been described in rat hepatocytes [23].

Acknowledgements. These studies were supported by grants from the Medical Research Council and the British Diabetic Association. J.P. is on leave of absence from the Central University of Venezuela whose financial support is gratefully acknowledged. The perifusion chambers were built with support from Grant No. S1-493, Conicit, Venezuela. We thank Michael R. Christie for skilful technical assistance. Plasma growth hormone concentrations were very kindly measured for us by Dr. J. G. Schofield, Dept. of Biochemistry, University of Bristol, to whom we express our grateful thanks.

\section{References}

1. Houssay BA, Biasotti A (1931) The hypophysis, carbohydrate metabolism and diabetes. Endocrinology 15: 511-523

2. Young FG (1939) Anterior pituitary fractions and carbohydrate metabolism. I. The preparation and properties of diabetogenic extracts. J Endocrinol 1: 339-354

3. Houssay BA, Rodriguez RR, Cardeza AF (1953) Accion diabetogena de la hormona de crecimiento de la hipofisis. Rev Soc Argent Biol 29: 33-41

4. Campbell J (1955) Diabetogenic actions of growth hormone. In: Smith Jr RN, Gaebler OH, Long CNH (eds) The hypophyseal growth hormone, nature and actions. McGraw-Hill, New York, p 270-285

5. Campbell J, Rastogi KS (1966) Growth hormone-induced diabetes and high levels of serum insulin in dogs. Diabetes 15: $30-43$

6. Pierluissi J, Norwich KH, Green GR, Campbell J (1978) Insulin kinetics in metasomatotropic diabetes. Metabolism 27: $61-70$

7. Haist RE, Kinash B (1951) Effect of purified growth hormone on growth of islets of Langerhans in hypophysectomized, intact and glucose-injected rats. Fed Proc 10: 58

8. Bencosme SA, Tsutsumi V, Martin JM, Akerblom HK (1971) Ultrastructural changes in $\beta$-cells of pancreatic islets from rats with elevated levels of circulating growth hormone secreted by MTT-W15 tumor. Diabetes 20: 15-26

9. Martin JM, Gagliardino JJ (1967) Effect of growth hormone on the isolated pancreatic islets of rat in vitro. Nature 213: 630-631

10. Malaisse WJ, Malaisse-Lagae F, King S, Wright PH (1968) Effect of growth hormone on insulin secretion. Am J Physiol 215: $423-428$
11. Coll-Garcia E, Gill JR (1969) Insulin release by isolated pancreatic islets of the mouse incubated in vitro. Diabetologia 5: 61-66

12. Nielsen JH, Anderson A, Frimodt-Moller C (1979) Preservation of $\beta$-cell function in adult human pancreatic islets for several months in vitro. Diabetologia 16:97-100

13. Krebs HA, Henseleit K (1932) Untersuchungen über die Harnstoffbildung im Tierkörper. Hoppe-Seylers Z Physiol Chem 210: 33-66

14. Schofield JG (1966) Studies on the secretion of growth hormone. Ph. D. Thesis, University of Cambridge, $\mathrm{p} 12-23$.

15. Ashcroft SJH, Crossley JR (1975) The effects of glucose, Nacetylglucosamine, glyceraldehyde and other sugars on insulin release in vivo. Diabetologia 11: 279-284

16. Bergmeyer HU, Bernt E, Schmidt F, Stork H (1974) Determination with hexokinase and glucose-6-phosphate dehydrogenase. In: Bergmeyer HU (ed) Methods of enzymatic analysis, vol 3. Academic Press, New York London, p 1196-1198

17. Snedecor GW, Cochran NG (1967) Statistical methods, 6th ed. Iowa State College Press, Ames, Iowa

18. Pierluissi J (1979) Insulin and glucagon levels in young dogs treated with growth hormone. In: Pierluissi J (ed) Endocrine pancreas and diabetes. Excerpta Medica Int Congr Series 459: 220-229

19. Sirek A, Vranic M, Sirek OV (1979) Effect of a single injection of somatotrophin (STH) on plasma insulin (IRI) and glucagon (IRG) levels in the dog. In: WaldhäusI W, Alberti KGMM (eds) 10th Congress of the International Diabetes Federation. Excerpta Medica Int Congr Series 481: 217-218

20. Chochinov RH, Daughaday WH (1976) Current concepts of somatomedin and other biologically related growth factors. Diabetes 25: 994-1007

21. Tai TY, Pek S (1976) Direct stimulation by growth hormone of glucagon and insulin release from isolated rat pancreas. Endocrinology 99: 669-677

22. Pek S, Tai TY, Crowther R, Fajans SS (1976) Glucagon release precedes insulin release in response to common secretagogues. Diabetes 25: 764-770

23. Donner DB, Nakayama K, Tani S, Lutz U, Sonemberg M (1978) The uptake and degradation of growth hormone fragments by rat hepatocytes. J Biol Chem 253: 6717-6723

Received: December 24, 1979,

and in revised form: May 22, 1980

S. J. H. Ashcroft

Nuffield Department of Clinical Biochemistry

John Radcliffe Hospital

Headley Way

Headington

Oxford OX3 9DU

England 